\title{
KLK2 wt Allele
}

National Cancer Institute

\section{Source}

National Cancer Institute. KLK2 wt Allele. NCI Thesaurus. Code C49719.

Human KLK2 wild-type allele is located in the vicinity of $19 q 13.41$ and is approximately 7 $\mathrm{kb}$ in length. This allele, which encodes kallikrein-2 protein, is involved in vasodilation and smooth muscle contraction via the proteolytic cleavage of kininogen to release lysylbradykinin (kallidin). 